\title{
Parental and Gender Effects on the Entrepreneurial Intention of University Students in South Africa
}

\author{
Olawale Fatoki \\ Department of Business Management, Turfloop Campus, \\ University of Limpopo, Limpopo Province, South Africa \\ Email: Olawale.fatoki@ul.ac.za
}

\section{Doi:10.5901/mjss.2014.v5n7p157}

\section{Abstract}

The aim of the study is to investigate empirically whether there is a significant difference in the entrepreneurial intention of students whose parents run a business and those whose parents do not run a business. In addition, the study aims to investigate whether there is a significant gender difference in the entrepreneurial intention of students. The study focussed on the final year students (undergraduate level) in the Department of Business Management of a South African university. These are students that have done entrepreneurship and small business management modules. This study made use of convenience sampling. Data was collected through the use of self-administered questionnaire in a survey. Data analysis included descriptive statistics and the T-test. The results indicate that although male students have a higher level of entrepreneurial intention compared to female students, the difference is not statistically significant. The results also indicate that students whose parents are involved in business have a higher level of entrepreneurial intention compared to students whose parents are not involved in business. However, the difference is not statistically significant.

Keywords: parent, gender, entrepreneurial intention, university students, South Africa

\section{Introduction}

Graduate unemployment rate is on the increase in South Africa due to lack of job opportunities. According to Van Der Berg and Van Broehuizen (2012), graduate unemployment in South Africa (where 'graduates' are considered to be those with at least university degree) is quite low in an international context. Graduate unemployment has risen extremely modestly even during the current difficult global and domestic economic conditions. City Press (2012) however reports that university degrees or diplomas no longer hold the promise of jobs for young South Africans as hundreds of thousands of them battle to find work. There are about 600, 000 university graduates that are languishing at home. Not all graduates are equal in the fierce battle for jobs.

Entrepreneurship offers unemployed university graduates a way to become employed and also create jobs. However, South Africa's early-stage entrepreneurial activity as measured by the Total Early-Stage Entrepreneurial Activity (TEA) is below the average when compared to countries with a similar economic development level. According to Turton and Herrington (2012), South Africa's TEA rate decreased from 9.1\% in 2011 to $7.3 \%$ in 2012. It is significantly below the average of efficiency-driven countries (14.3\%). In addition, South Africa's rate of perceived opportunities is $36 \%$, below the average for efficiency-driven economies of $41 \%$. The country's rate for perceived capabilities is $40 \%$, below the average for efficiency-driven economies of $52 \%$. The results of the cross tabulation of perceived opportunities with that for perceived capabilities reveal that the pool of potential entrepreneurs in South Africa is $19 \%$ of the adult population. Potential entrepreneurs are individuals who intend to pursue a business opportunity within the next three years. Furthermore, South Africa's pool of intentional entrepreneurs is $14 \%$, which is well below the average for efficiency-driven countries of $27 \%$.

According to Beeka and Rimmington (2011) and Buang (2011), entrepreneurship is one of the career options for youths and graduates. Therefore, it is critical to understand the factors that affect their intentions to start-up a business in the future. Ashley-Cotleur et al. (2009) point out that there are a number of individual factors that motivate a person's decision to become an entrepreneur. These can generally be categorized as (1) demographic variables or (2) attitudes, values or psychological factors. Two key demographic variables that influence entrepreneurship activities are gender and family/parental background. Wang et al. (2011) note that understanding the antecedents of entrepreneurial intention allows teachers, consultants, advisors and policy makers to get a clearer picture of how intentions are formed and how new venture founders' beliefs, perceptions and motives impact the intent to start a business. Investigating the motives 
that drive graduating students to entrepreneurship is highly significant given the importance of entrepreneurship to job creation and economic growth (Zellweger et al. 2011).

\section{Objective of the Study}

The objective of the study is to determine the influence of gender and the involvement of parent(s) in business on the entrepreneurial intention of potential university graduates. The study will investigate empirically whether there is a significant difference in the entrepreneurial intention of students whose parents run a business and those whose parents do not run a business. In addition, the study will investigate whether there is a significant gender difference in the entrepreneurial intention of students. This study extends the previous study on graduate entrepreneurial intention by the same author (Fatoki, 2010). The previous study mixed both business and non-business students together in reaching its conclusions. This study focussed specifically on the final year business students (undergraduate level) that have done entrepreneurship and small business management modules.

\section{Literature Review}

The literature has failed to come up with one specific definition which totally describes entrepreneurship. Various definitions have emerged in an attempt to explain entrepreneurship. According to Sathiabama (2010), entrepreneurship is a dynamic process of creating wealth by individuals or groups of individuals. Rwigema and Venter (2004) define entrepreneurship as the process of conceptualising, organising, launching and through innovation, nurturing a business opportunity into a potentially high growth venture in a complex and unstable environment. Entrepreneurship is a vehicle to economic growth, success and prosperity. Herrington et al. (2009) point out that an entrepreneur is one that shifts economic resources out of an area of low productivity into an area of higher productivity and greater yield. An entrepreneur is one who organises, manages and assumes the risk of a business enterprise

According to Pihie (2009) entrepreneurship can be measured in two ways: Actual entrepreneurship (i.e. people that have actually started business) and entrepreneurial intention (i.e. people that intend to start business). A strong association exists between the entrepreneurial intention and actual behaviour. Henley (2007) points out that entrepreneurship is an intentional activity, in that for many those intentions are formed at least a year in advance of new venture creation. Ajzen's (1991) theory of planned behaviour argues that there is a link between beliefs and behavior. This suggests that there is a relationship between the intention to be an entrepreneur and the act of becoming one. Thus, one's intention greatly explains the behaviour. The underlying assumptions of the theory of planned behaviour are that: Much human behaviour is planned and therefore preceded by intention towards that behaviour; human beings are rational and make systematic use of information available to them when making decisions; and intention predicts planned behaviour. In addition, the social learning theory by Bandura (1977) states that behavior is learned from the environment through the process of observational learning. Children observe the people around them behaving in various ways. Individuals that are observed are called models.

According to Ashley-Cotleur et al. (2009), there are a number of individual factors that motivate a person's decision to become an entrepreneur. These can generally be categorized as (1) demographic variables or (2) attitudes, values or psychological factors. Demographic variables that influence entrepreneurship activities include gender and family background. Having role models is a significant factor in wanting to start a business. Self-employed parents can act as mentors and guides for children starting their own businesses. Zellweger et al. (2011) point out that growing up in a family where parents are owners of a company represents a particular context in which career intentions are formed. Parents serve as positive role models. Thus, offspring from business families should be more motivated to start their own firm than children without this background. This can be due to family support in terms of resources needed to start a business, learning effects, or strengthened perceptions about mastery of the challenges related to an entrepreneurial career. Genetic heritage, the actual possibilities for learning on the job provided by a family business or financial support can influence the choice of for entrepreneurship by children of parents involved in entrepreneurship (Georgellis et al. 2005); (Fairlie and Robb, 2007); Bosma et al. 2012). Experiences during early childhood and socialization at home and in school probably shape the attitudes of young people towards entrepreneurship (Basu and Virick, 2008).

Carr and Sequeira (2007) point out that individuals with prior family business experience may incorporate their experiences, such that their attitudes and behaviours towards entrepreneurial action are shaped positively or negatively towards business ownership. Bagheri and Pihie (2010) explain that growing up in a family where parents establish and run a business provides an inspiring and supportive environment and the requisite information and resources to launch a business. In addition, it gives the opportunity to experience the realities and challenges of the business world. Engle et al. 
(2011), Tanveer et al. (2013) and Sivarajah and Achchunthan (2013) find a positive relationship between the involvement of parents in business and the entrepreneurial intention of students.

According to Karimi et al. (2012), gender difference is a fundamental socio-cultural dimension that influences entrepreneurship. Despite the increasing the number and share of women entrepreneurs entrepreneurship is still a malestereotyped domain and associated with masculine traits and women's entrepreneurship is still significantly lower than male. Koellinger et al. (2013) find that the lower rate of female business ownership is primarily due to women's lower propensity to start businesses rather than to differences in survival rates across genders. Women are less confident in their entrepreneurial skills, have different social networks and exhibit higher fear of failure than men. These variables explain a substantial part of the gender gap in entrepreneurial activity. Ahmed et al. (2010) however find that no significant relationship between gender and the intention to become an entrepreneur.

\section{Research Methodology}

The study focused on the final year students (undergraduate level) in the Department of Business Management at a selected University located in the Limpopo Province of South Africa. These are students whose curriculum includes entrepreneurship and small business management in their first and second years in the university. This study made use of convenience sampling. Data was collected through the use of self-administered questionnaire in a survey. The questionnaires were distributed in class to the students with the assistance of the lecturer. Following similar studies on entrepreneurial intention by Zhao et al. (2005), Zampetakis and Moustakis (2006) and Wu (2009), entrepreneurial intention was measured using seven point Likert scale. Seven statements were used. 1. I will start my own business in the near future. 2. It is has been my intent to start my own business. 3. Starting my own business is an attractive idea to me, 4. I am enthusiastic about starting my own business, 5 . It is desirable for me to start my own business. 6 . I spent a lot of time thinking about owning my own business. 7. Owning my own business is the best alternative for me. The seven measures were averaged to obtain the entrepreneurial intention score for each respondent. Reliability was measured using the Cronbach's alpha. The coefficient alpha for the measures of entrepreneurial intention was 0.88 , which indicated a very high reliability. Gender was measured using 1 for male and 2 for female. Parents refer to whether an individual has parents (guardians) that are entrepreneurs. 1= does not have parent who is an entrepreneur, 2 =has parent who is an entrepreneur. Data analysis included descriptive statistics (mean and standard deviation) and the T-test.

\section{Results and Discussions}

180 questionnaires were distributed in class with the assistance of the lecturer and 165 were returned. The response rate was $91.7 \%$. 10 questionnaires were found unusable because of the failure of the respondents to complete vital parts of the questionnaire. 155 questionnaires were found usable. 68 respondents were male and 87 were female. 62 respondents had one or both parents (guardians) involved in business and 93 respondents did not have any of the parents involved in business.

\subsection{Gender and the Entrepreneurial Intention of Business Students}

Table 1: gender and the entrepreneurial intention of business students

\begin{tabular}{|c|c|c|}
\hline Gender & Mean of entrepreneurial intention & Standard deviation \\
\hline Male & 5.731 & 1.029 \\
\hline Female & 5.521 & 1.198 \\
\hline
\end{tabular}

Table 1 depicts the results of entrepreneurial intention for male and female respondents. The mean for the entrepreneurial intention of male students is 5.731. The mean for the entrepreneurial intention of female students is 5.521. This indicates a high level of entrepreneurial intention for business students. A previous study on the entrepreneurial intention of students by the same author (Fatoki, 2010) finds a low level of entrepreneurial intention by university students in general. However, the previous study (Fatoki, 2010) mixed both business and non-business students together in reaching its conclusions. Out of the 701 respondents in the previous study, only 230 respondents had taken business courses and 471 respondents had never taken business courses. In addition, the previous study used a five point Likert scale. The present study focused only on business students who have taken courses on entrepreneurship and small business management. The study used a seven-point Likert scale. Studies such as Grubb et 
al. (2006), Souitaris et al. (2007) and Gerba (2012) find that university students whose primary discipline is business management possess a more favourable view of careers in small business. Entrepreneurial education programs are a source of entrepreneurial attitude and overall intentions to become future entrepreneur. Business graduates are more likely to launch businesses and have a higher level of intention and a more developed perception of self-efficacy. Turton and Herrignton (2012) point out that South Africa's pool of intentional entrepreneurs is 14\%, which is well below the average for efficiency-driven countries of $27 \%$. The results of this study however suggest a high level of entrepreneurial intention among business students who have taken modules in entrepreneurship and small business management. This underscores the importance of business and entrepreneurship education in improving entrepreneurial intention and the general level of entrepreneurship in South Africa.

The results indicate that male respondents (mean of 5.731) have a higher level of entrepreneurial intention compared to female respondents (mean of 5.521). The T-test (sig. 0.307) indicates that there is no significant difference in the mean scores of male and female respondents. Thus it can be concluded that there is no significant gender difference in the entrepreneurial intention of business students. The literature is inconclusive about the effect of gender on entrepreneurial intention. Veciana et al. (2005) and Zhou et al. (2005) find that compared to men, women have lower entrepreneurial career intentions. Gerba (2012) however finds no significant difference in the entrepreneurial intention of male management students and female management students.

\subsection{Parents' involvement in business and the entrepreneurial intention business students}

Table 2: Parents' involvement in business and the entrepreneurial intention of business students

\begin{tabular}{|l|c|c|}
\hline \multicolumn{1}{|c|}{ Parent involvement in business } & Mean of entrepreneurial intention & Standard deviation \\
\hline Parent(s) currently runs a business & 5.731 & 1.029 \\
\hline Parent(s) do not run a business & 5.521 & 1.198 \\
\hline
\end{tabular}

Table 2 depicts the results of parents' involvement in business and the entrepreneurial intention of business students. The results indicate that students whose parents are involved in business (mean of 5.873) have a higher level of entrepreneurial intention compared to students whose parents are not involved in business (mean of 5.439). The T-test (sig. 0.438) however indicates that there is no significant difference in the mean scores of the two sets of respondents. Though students whose at least one parent is involved in running a business have greater mean score than those students whose parents are not involved in business, the mean difference is not statistically significant. Thus it can be concluded that there is no significant difference in parents' involvement in business and the entrepreneurial intention of business students. The results are consistent with previous empirical studies on the impact of family involvement in business and entrepreneurial intention. Olomi and Sinyamule (2009) find a positive association between entrepreneurial family background and entrepreneurial intention. Gerba (2012) finds that the mean score for students whose family members are involved in business is higher than those whose family members are not involved in business. However, the difference is not statistically significant.

\section{Conclusions}

Graduate unemployment rate is on the increase in South Africa due to lack of job opportunities. Entrepreneurship offers unemployed university graduates a way to become employed and also create jobs. The objective of the study is to determine the influence of gender and the involvement of parent(s) in business on the entrepreneurial intention of potential university graduates who have done entrepreneurship and small business management modules. The study investigates whether there is a significant difference in the entrepreneurial intention of students whose parents run a business and those whose parents do not run a business. In addition, the study will investigate whether there is a significant gender difference in the entrepreneurial intention of students. The results indicate that male students have a higher level of entrepreneurial intention compared to female respondents. The T-test indicates that there is no significant difference in the mean scores of male and female respondents. In addition, the results indicate that students whose parents are involved in business have a higher level of entrepreneurial intention compared to students whose parents are not involved in business. The T-test however indicates that there is no significant difference in the mean scores of the two sets of respondents. Though students whose at least one parent is involved in running a business have greater mean score than those students whose parents are not involved in business, the mean difference is not statistically significant. $\%$. The results of this study underscore the importance of business and entrepreneurship education in improving 
entrepreneurial intention and the general level of entrepreneurship in South Africa. Future research could expand the study to more universities to improve the generalisability of the study.

\section{References}

Ahmed, I., Nawaz, MM., Ahmad, Z., Shaukat, M.Z., Rehman, W., \& Ahmed, N. (2010). Determinants of Students' Entrepreneurial Career Intentions: Evidence from Business Graduates. European Journal of Social Sciences, (15(2): 14-22.

Ashley-Cotleur, Catherine, King, Sandra, \& Solomon, George. (2009). Parental and gender influences on entrepreneurial intentions, motivations and attitudes. [Online] Available: http://usasbe.org/knowledge/proceedings/proceedings (December 10, 2013)

Ajzen, I., (1991). The theory of planned behavior. Organizational Behaviour and Human Decision Processes, 50 (2), 179-211.

Bagheri, A., \& Pihie, Z.A.L. (2010). Role of family in entrepreneurial leadership development of university students. World Applied Science. Journal, 11: 434-442.

Bandura, A. (1991). Social-cognitive theory of self-regulation. Organizational Behaviour and Human Decision Processes, 50, $248-287$.

Basu, Anuradha, \& Virick, Meghna, (2008) Assessing entrepreneurial intentions amongst students: A comparative study. [Online] Available: http://works.bepress.com/anuradha_basu/12/ (December 15, 2013)

Beeka, B.H., \& Rimmington, M. (2011).Entrepreneurship as a career option for African youths. Journal of Development entrepreneurship , 16(1): 145-164.

Bosma, N., Hessels, J., Schutjen, V., van Praag, M., \& Verheul I. (2012). Entrepreneurship and role models. Journal of Economic Psychology, 33: 410-424.

Brush, C. G., Carter, N. M., Gatewood, E. J., Greene, P. G., \& Hart, M. M. (2006). Growth oriented women entrepreneurs and their businesses: A global research perspective. (1 ${ }^{\text {st }}$ ed.). Cheltenham: Edward Elgar.

Buang, N.A. (2011). Entrepreneurship Career Paths of Graduate Entrepreneurs in Malaysia. Research Journal of Applied Sciences, 6(4): 282-289.

Carr, J.C., \& Sequeira, J.M. (2007). Prior family business exposure as intergenerational influence and entrepreneurial intent: A Theory of Planned Behaviour approach. Journal of Business Research, 60, 1090-1098.

City Press 2012. Young, jobless and desperate. Degrees with no guarantees. [Online] Available:http://www.citypress.co.za /SouthAfrica/News/Young-jobless-and-desperate-Degrees- with-noguarantees-20120616. (August 19, 2013)

Engle, R.L., Dimitriadi, N., Gavidia, J.V., Schlaegel, C., Delanoe, S., Alvarado, I., He, X., Buame, S. and Wolff, B. (2010). Entrepreneurial Intent: A Twelve-Country Evaluation of Ajzen's Model of Planned Behaviour. International Journal of Entrepreneurial Behaviour \& Research, 16(1): 35-57.

Fairlie, R.W., \& Robb, A. (2007). Families, Human Capital, and Small Business: Evidence from the Characteristics of Business Owners. Industrial and Labor Relations Review, 60(2):225-245

Fatoki, O.O. (2010). Graduate entrepreneurial intention in South Africa: motivations and obstacles. International Journal of Business Management, 5(9): 87-98

Georgellis Y., Sessions, J.G., \& Tsitsianis, N. (2005). Windfalls, wealth, and the transition to self-employment. Small Business Economics, 25 407-428.

Gerba, D.T. (2012). Impact of entrepreneurship education on entrepreneurial intentions of business and engineering students in Ethiopia. African Journal of Economic and Management Studies, 3(2): 258 - 277.

Grubb, W.L., Harris, M.L. \& MacKenzie, W.I. (2006). Business students' perceptions of employment in small and medium-sized enterprises versus multinational corporations: investigating the moderating effect of academic major, gender and personality. Journal of Small Business Strategy, 17(2): 27-36.

Henley, A. (2007). From entrepreneurial aspiration and transition to business start up: evidence from British longitudinal data. Entrepreneurship and Regional Development, 19(3): 253-280.

Herrington M, Kew J, Kew P 2009. Global Entrepreneurship Monitor, South African Report [Online] Available: http://www.gbs.nct.ac.za/gbswebb/userfiles/gemsouthafrica2000pd (April 15, 2013].

Koellinger, P., Minniti, M., \& Schade, C. (2013). Gender Differences in Entrepreneurial Propensity. Oxford Bulletin of Economics and Statistics, 75(2): 213-234.

Karimi, S., Biemans, J.A., Lans, T., Chizari, M., Mulder, M., \& Mahdei, K.M. (2013). Understanding role models and gender influences on entrepreneurial intentions among college students. Procedia - Social and Behavioral Sciences, 93, 204-214

Olomi, D.R., \& Sinyamule, R.S. (2009). Entrepreneurial inclinations of vocational education students: a comparative study of male and female trainees in Iringa region, Tanzania. Journal of Enterprising Culture, 17(1): 103-25.

Pihie, ZAL. (2009). Entrepreneurship as a career choice: an analysis of entrepreneurial self-efficacy and intentions of university students. European Journal of Social Sciences, 9(2): 338-349.

Rwigema \& Venter. (2004). Advanced entrepreneurship. Advanced Entrepreneurship. (1 ${ }^{\text {st }}$ ed.) Cape Town: Oxford University Press Southern Africa.

Sathiabama, K. (2010). Rural women empowerment and entrepreneurship development [Online]. Available: http://www.microfinancegateway.org/ga (August 15, 2010)

Sivarajah, K., \& Achchuthan, S. (2013). Entrepreneurial Intention among Undergraduates: Review of Literature. European Journal of Business and Management, 5(5) 172-186.

Souitaris, V., Zerbinati, S., \& Andreas, A. (2007). Do entrepreneurship programmes raise entrepreneurial intention of science and 
engineering students? The effect of learning, inspiration and resources. Journal of Business Venturing, 22(4): 566-591.

Van der Berg, Servaas, \& Van Broekhuizen, Hendrik, (2012). Graduate unemployment in South Africa: A much exaggerated problem. [Online] Available: http://www.econ3×3.org/article/how-high-graduate-unemployment-south-africa-much-needed-update (May 12, 2013).

Veciana, J,M., Aponte, M., \& Urbano, D. (2005). University students' attitudes towards entrepreneurship: a two countries comparison. International Entrepreneurship and Management Journal, 1(2): 165-182.

Vesalainen, J., \& Pihkala, T. (2000). Entrepreneurial identity, intentions and the effect of the push-factor. International Journal of Entrepreneurship, 3(2), 145-151.

Tanveer. M.A., Zafar, S., Shafique, R., Jhangir, M., \& Rizvi, S. (2013). Motivational Factors and Students Entrepreneurial Intention in Pakistan. Journal of Basic and Applied Scientific Research, 3(4)263-269

Turton, Natasha, \& Herrington, Mike, (2013). Global Entrepreneurship Monitor South African 2012 Report. [Online]. Available: http://www.gemconsortium.org/docs/2801/gem-south-africa-2012-report (December 22, 2013)

Wang. W., Lu, W., \& Millington, J.K. (2011). Determinants of Entrepreneurial Intention among College Students in China and USA. Journal of Global entrepreneurship research, 1(1):35-44

Wu, Jinpei, (2009). Entrepreneurial Orientation, Entrepreneurial Intent and New Venture Creation: Test of a Framework in a Chinese Context. [Online]. Available: http://scholar.lib.vt.edu/theses/available/etd-07142009-160704/unrestricted/JinpeiWu.pdf (December 18, 2013)

Zampetakis, L.A., \& Moustakis, V. (2006). Linking creativity with entrepreneurial intentions, A structural approach. The International Entrepreneurship and Management Journal, 2(3), 413- 428.

Zellweger, T., Sieger, P., \& Halter, F. (2011). Should I stay or should I go? Career choice intentions of students with family business background. Journal of Business Venturing, 26(5):521-536

Zhao, H., Seibert, S. E., \& Hills, G. E. (2005). The mediating role of self-efficacy in the development of entrepreneurial intentions. Journal of Applied Psychology, 90(6): 1265-1272. 